Nippon Suisan Gakkaishi ～81(5), 864 (2015)

\title{
シンポジウム記録 魚類行動生理学の基礎と水産研究への応用
}

\section{I -2．太平洋サケの母川記銘・回帰行動の生理機構}

上田 宏

北海道大学北方生物圏フィールド科学センター・ 大学院環境科学院

I-2. Physiological mechanisms of imprinting and homing migration in Pacific salmon HiRoshi UEDA

Field Science Center, Graduate School of Environmental Science, Hokkaido University, Sapporo, Hokkaido 0600809, Japan

太平洋サケは，稚幼魚が生まれた川（母川）から海に 降河する時に，母川の何らかの因子を記憶(記銘)する。 その後, 大海原を数年間索䬣回遊しながら成長して親魚 になり，性成熟の開始が引き金となって産卵回遊を開始 して母国の沿岸まで回遊する。彼らは記銘した母川の因 子を想起して遡河し，繁殖して子孫を残して一生を終え るというドラマチックな生活史を営む。母川の因子に関 しては，1950 年代に米国で，母川固有の二オイである という嗅覚仮説が提唱された。しかし，半世紀以上たっ た今も，稚幼魚がぞのように母川の二オイを記銘し，親 魚がぞのようにその二オイを想起するのか，また母川固 有の二オイはどのような成分であるのかは不明な点が多 く残されている。

太平洋サケの稚幼魚が降河回遊する時は，銀化をして 海水適応能を獲得するので, 銀化に関連する様々な内分 泌的変化の研究が行われてきた。その中でも特に脳一下 垂体一甲状腺（BTT）系ホルモンが銀化に重要な役割を 演じることが報告されてきたが，母川記銘に関する研究 は行われてこなかった。そこで，千歳ふ化場から千歳川 と石狩川を経て石狩湾に降河回遊するシロザケ稚魚をサ ンプリングしてBPT 系ホルモンの動態を解析した。ふ 化場から放流直後に脳内の甲状腺刺激ホルモン放出ホル モン（TRH）遺伝子発現量が増加し，降河回遊中に脳 下垂体の甲状腺刺激ホルモン（TSH） $\beta$ サブユニット遺 伝子発現量, および体内の甲状腺ホルモン $(\mathrm{T} 3 ・ \mathrm{~T} 4)$ 含有量が増加した。哺乳類では, 記憶に関連する因子と して海馬に存在するNMDA 型グルタミン酸受容体 （NMDA 受容体）が重要な役割を演じていることが報 告されている。NMDA 受容体の必須サブユニットであ る NR1 遺伝子発現量は, シロザケ稚魚の降河回遊に伴 い，TRH 遺伝子発現量が増加した後に増加した。シロ ザケ稚魚は，子化場から河川に放流される環境の変化が 刺激になり，TRH が活性化され，母川の二オイを記銘 する可能性が示唆された。
太平洋サケの親魚が産卵回遊して母川回帰する時は, 生殖腺の成熟と密接な関係があるため, 性成熟に関連す る種々の内分泌学的変化の研究が行われてきた。その中 でも特に脳一下垂体-生殖腺（BPG）系ホルモンが重要 な役割を演じることが報告されてきたが，母川想起に関 する研究は少なかった。そこで, ベーリング海から千歳 ふ化場に回帰するシロザケ親魚をサンプリングして BPG 系ホルモンの動態を解析した。脳のサケ型生殖腺 刺激ホルモン放出ホルモン $(\mathrm{sGnRH})$ 前駆体遺伝子発 現量は，脳部位ごとに発現のピークが異なるが増加する 傾向を示し，また雄の終脳と視床下部においてベーリン グ海で高い発現量を示す傾向が認められた。脳下垂体か ら分泌される生殖腺刺激ホルモン (LH) 量抢よび血中 ステロイドホルモン $(\mathrm{E} 2 ・ \mathrm{~T} ・ 11 \mathrm{KT} ・ \mathrm{DHP})$ 量は, 多 少の雌雄差は認められるが産卵回遊抢よび遡河回遊に伴 い増減した。NR1 遺伝子発現量は, 雌雄とも遡河回遊 に伴い増加したが，雄の終脳においてベーリング海でも 高值を示した。石狩湾に扔いて捕獲した海水中のシロザ ケ親魚に $\mathrm{GnRH}$ アナログ (GnRHa) を投与したところ, NR1 遺伝子発現量が雄の嗅球で増加した。さらに, 石 狩川水系河川水に対する嗅覚応答 (EOG) を測定した ところ, GnRHa 投与した雄親魚の石狩川水と千歳川水 に対する EOG が上昇した。ベーリング海から尔化場に 回帰するシロザケは, ベーリング海において $\mathrm{sGnRH}$ が 活性化して産卵回遊を開始し, 遡河回遊にも $\mathrm{sGnRH}$ が 主導的役割を果たして母川想起する可能性が示唆された。

母川固有の二オイに関しては，4 種の太平洋サケ（サ クラマス・ベニザケ・シロザケ・カラフトマス）を用い た $\mathrm{Y}$ 字水路に打ける人工河川水の選択行動実験打よび 種々の河川水に対する EOG 実験により, 各河川で組成 が異なり，季節抢よび年により変化しない溶存遊離アミ ノ酸（DFAA）組成が重要であることを確認している。 また, 河床の付着微生物の集合体であるバイオフィルム が放出する DFAA 組成が，河川水中の DFAA 組成と同 じであることから，DFAAの起源の一つはバイオフィ ルムであると考えている。科学技術振興機構 (JST) の 復興促進プログラムにより実施した「東北地方の高回帰 性サケ創出プロジェクト」において, 岩手県の下安家子 化場から NR1 遺伝子発現量を増加させる効果がある $\omega 3$ 含有䭒料をサクラマススモルト 1,500 尾に給慨し, PIT タグ標識して放流したところ， 1 年後の夏〜秋に 5 尾が回帰した（回帰率 $0.333 \%$ ）。安家川におけるサク ラマス親魚の回帰率は過去最高で $0.118 \%$ であるので, 約 3 倍の効果が認められた。今後, 母川記銘機能を向 上させて，我国の太平洋サケ資源を安定的に回帰させる 人工ふ化放流技術に応用されることが期待される。 